DOI https://doi.org/10.30525/978-9934-26-114-5-39

\title{
ВПРОВАДЖЕННЯ БАТЬКІВСЬКИХ ІНТЕРНЕТ-ЗБОРІВ ЯК ОДИН 3 ЧИННИКІВ СТВОРЕННЯ ЄДИНОГО ІНФОРМАЦЙНОГО ПРОСТОРУ «ШКОЛА-ДІМ» У ЗАКЛАДІ ЗАГАЛЬНОЇ СЕРЕДНЬОЇ ОСВІТИ
}

\author{
Свистунова Т. М. \\ аспірант кафедри освітологї та інноваційної педагогіки \\ Харківський національний педагогічний університет \\ імені Г. С. Сковороди \\ м. Харків, Украӥна
}

На сучасному етапі розвитку інформаційних технологій взаємодію школи та сім’і в нашій країні необхідно розвивати в наступних напрямках: 1) створювати Інтернет-сайт в кожній школі, з обов'язковими сторінками для батьків; 2) проводити освітню роботу з батьками; 3) втілювати електронне спілкування між батьками та шкільними вчителями, класними керівниками, адміністрацією. Розглянемо електронне спілкування з точки зору доцільності і можливості втілення в сучасну українську освіту.

Для побудови єдиного інформаційного середовища школи необхідно будувати інтерактивну взаємодію між всіма учасниками навчально-виховного процесу, використовувати у цій взаємодії всі сучасні засоби комп'ютерного спілкування: електронну пошту, Viber, Zoom, Telegram, ICQ, Google Meet, Skype, WhatsApp, надавати батькам доступ до електронних журналів.

Важливим напрямом інтерактивної взаємодії школи з батьками $\epsilon$ проведення Інтернет-зборів. На сьогодні у вітчизняній педагогічній науці загалом не опрацьовані теоретичні та методичні питання створення та проведення Інтернет-зборів для батьків. Крім того, досвіду проведення батьківських Інтернет-зборів на шкільному рівні на Україні, як й у пострадянських державах ще занадто малий. Однак така форма взаємодії з батьками є досить перспективною, що у нинішньому столітті, неминуче стане реальністю, зумовленою інформатизацією й комп'ютеризацією суспільства.

Необхідними умовами проведення батьківського Інтернет-збору $\epsilon$ [1, c. 223]: 
- наявність у групи педагогів, адміністрації, розробників сайтів зацікавленості у впровадженні в практику взаємодії з батьками нових інформаційних технологій;

- наявність у більшості батьків комп'ютерної техніки 3 підключенням до мережі Інтернет;

- підготовленість координаторів зборів, попереднє ознайомлення батьків з обговорюваними проблемами, відправлення батькам електронних повідомлень про проведення зборів та розповсюдження інформації про збори в навчальних закладах.

Активний зворотній зв'язок на Інтернет-зборах допомагає включати зауваження і пропозиції зацікавлених батьків, сприятиме поліпшенню зв'язків між органами освіти та батьками. Вимагають уточнення, узагальнення і визначення такі нові форми інтернактивної взаємодії сім'ї та школи, як батьківська відеоконференція, вебінари та форуми батьків в мережі Інтернет.

Інтернет-конференція та Інтернет-форум - це інтерактивні форми роботи 3 користувачами, де обговорюються будь-які хвилюючі та актуальні питання. Застосувавши такі форми спілкування в Інтернет можна отримати широке дослідження будь-яких психолого-педагогічних, методичних, медичних чи будь-яких шкільних проблем, порадитись 3 батьками, почути їх думку. Кінцевий ефект від взаємодії 3 батьками в значній мірі залежить від прийняття або не прийняття ними запропонованої інформації, іiі внутрішньої переробки та наявності бажання конструктивних змін. Інтернет-збори надають можливість кожному з батьків удосконалювати не лише свої особисті якості, a і комунікативні навички.

Розглянуті інтерактивні форми взаємодії з батьками, звичайно дуже зручно проводити на власному сайті школи де навчаються їх діти. Також до числа нових і продуктивних інтерактивних технологій з батьками, що можуть бути використані на сайті навчального закладу, можна віднести створення і функціонування батьківського Інтернетклубу, який буде сприяти формуванню мережної батьківської громадськості. Такий клуб дозволить виявити і з'єднати творчих, талановитих і активних батьків. Звичайно, клубна діяльність батьків з різних шкіл не повинна уніфікуватись, кожна школа повинна виходити 3 власних цілей по взаємодії з батьками. Але в цілому, мета таких клубів полягає залучення найбільш активних батьків до сумісної розробки та проведенню різних ініціатив для дітей (освітніх, дослідницьких, конкурсних проектів і програм). Формами клубної роботи можуть бути [2]:

- участь у українських та міжнародних Інтернет-проектах, пов'язаних з батьками; 
- розробка і проведення шкільних та регіональних Інтернетпроектів;

- Інтернет-проекти сумісні $з$ дітьми;

- канікулярні конференції, конкурси, вікторини;

- сумісні проекти з батьківськими Інтернет-клубами інших шкіл.

Протягом 2020/2021 навчального року в Харківському приватному ліцеї «Теорема» було проведено серію вебінарів та батьківських Інтернет-зборів. Ліцей працює за дистанційною формою навчання на платформі Moodle, тому і учні, і батьки розташовані по всій Україні та Європі. Платформою Інтернет-зборів слугував сервіс для проведення відеоконференцій та онлайн-зустрічей Zoom. Майданчиком для вебінарів слугувала многофункціональна платформа Bizon 365 на базі YouTube. Інформування батьків Ліцею виконано за допомогою Інтернет-розсилки на електронні адреси, облікови записи Viber та Telegram. При підготовці до Інтернет-зборів класні керівники та адміністрація обробили близько 200 електронних анкет батьків розроблених за допомогою cepвicy Google Forms. Тематика зборів відрізнялась в залежності від класу. Спільними темами для всіх батьків були «Інтернет-безпека школярів», «Правила успішного дистанційного навчання», ««Академічна доброчесність: що? як? для чого?» тощо. Спеціально для батьківських інтернет-зборів було підготовлено декілька відеороликів про систему оцінювання в Ліцеї, про правильне завантаження фото, аудіо, відео матеріалів на платформу, зі зверненням до батьків виступили представники адміністрації Ліцею. Батькам i педагогам надано дискусійний Інтернет-майданчик на форумі pecypcy: https://www.theorem.com.ua. Трансляції протягом навчального року відвідали понад 500 батьків. Для батьків, які не змогли підключитися до прямих ефірів, записи Інтернет-зборів було розміщено на сайті, а також на YouTube-каналі Ліцею «Теорема».

Таким чином, грамотна організована на сайті взаємодія з батьками, втілення таких форм як батьківські Інтернет-збори, форуми, конференції, створення батьківського Інтернет-клубу дозволить казати про формування єдиного інформаційного простору «Школа-дім» у закладі загальної середньої освіти, що явиться ефективним інструментом в реалізації основних задач взаємодії української освіти 3 батьками.

\section{Література:}

1. Свистунова T.M. Батьківські Інтернет-збори - нова форма роботи з батьками. Педагогічні шляхи реалізації загальноєвропейський 
цінностей у системі освіти України: 3б. наук. пращуь / За заг. Ред.. Г.С.Гребенюка. Харків, 2005. С. 221-225.

2. Рекомендації щодо сторінки для батьків на шкільному інтернетсайті, URL: http://metodcentr10.at.ua/publ/vikhovna_robota/rekomendaciji_shhodo_storinki_dlja_batkiv_na_shkilnomu_internet_sajti/10-1-0-14

DOI https://doi.org/10.30525/978-9934-26-114-5-40

\title{
ЗАСТОСУВАННЯ КОМП'ЮТЕРНИХ ТЕХНОЛОГІЙ ПРИ ВИКЛАДАННІ ХІМІЧНИХ ДИСЦИПЛІН
}

\author{
Chicap O. A. \\ кандидат педагогічних наук, \\ завідувач кафедри природничих дисичиллін \\ Черкаська медична академія \\ м. Черкаси, Україна
}

Впровадження комп'ютерних технологій у освітній процес закладів вищої медичної освіти відбувається надзвичайно швидкими темпами i абсолютно відповідає трендам розвитку цифрового суспільства. Дана тенденція відкриває широкі можливості для підвищення ефективності процесу навчання і сприяе підготовці молоді до майбутньої професійної діяльності у світі, де особливого значення набувають компетентності угалузі високих технологій та цифрові навички фахівців [2, с. 201].

Комп'ютерні технології мають широкі можливості при викладанні дисциплін природничого циклу. На лекціях застосовується інтерактивний мультимедійний програмно-технологічний навчальний комплекс на основі технології SMART Board. Він дозволяє використовувати динамічно-інтерактивну таблицю хімічних елементів Д. І. Менделєєва, що сприяє економії часу та підвищує інформативність. При натискання на потрібний хімічний елемент, на таблиці відкривається розгорнута інформація про нього, можна побачити кількість енергетичних рівнів, розміщення електронів по орбіталях, кількість електронів на зовнішньому енергетичному рівні. Це дає можливість швидко отримати дані для розв'язування задач, визначення валентності, написання окисно-відновних реакцій.

За допомогою ще однієї функції інтерактивного мультимедійного навчального комплексу можна вивчати різноманітне лабораторне 